\title{
Cytotoxic Activity of Apixaban on HeLa Cells: An In vitro Study
}

\section{Apiksabanın HeLa Hücreleri Üzerindeki Sitotoksik Aktivitesi: in vitro Bir Çalışma}

\author{
Research Article
}

\section{Özer Aylin Gürpınar', Emre Kubat ${ }^{2 *}$, Mehmet Ali Onur ${ }^{1}$}

'Hacettepe University, Faculty of Science, Department of Biology, Ankara, Turkey. 229 Mayıs State Hospital, Department of Cardiovascular Surgery, Ankara, Turkey.

\section{A B S T R A C T}

\begin{abstract}
A pixaban is a new oral anticoagulant which is commonly used in the prophylaxis and treatment of systemic A embolism and deep vein thrombosis. Venous thromboembolic events are important risk factors in cancer patients. Several studies have suggested that anticoagulant drugs may have an effect on tumor development and progression. In this study, we aimed to investigate the cytotoxic effect of apixaban on a cancer cell line HeLa cells derived from human cervical cancer. The viability of HeLa cells was examined at 24 and 48 hours of incubation and apixaban showed a cytotoxic effect in the highest dilution. In other dilutions, cell viability was similar to the control group. These results show that apixaban may reduce proliferation of cancer cells at high concentrations.
\end{abstract}

\section{Key Words}

Apixaban, new oral anticoagulant, venous thromboembolism, cytotoxicity, HeLa cells.

\section{öz}

\begin{abstract}
A piksaban, sistemik emboli ve derin ven trombozunun proflaksisi ve tedavisinde yaygın olarak kullanılan A yeni nesil bir oral antikoagülandır. Venöz tromboembolik olaylar, kanser hastalarında önemli birer risk faktörüdür. Bazı çalışmalar, antikoagülan ilaçların tümör gelişimi üzerinde etkisi olabileceğini göstermektedir. Bu çalışmada, insan serviks kanseri kaynaklı hücre hattı HeLa hücreleri üzerinde apiksabanın sitotoksik etkileri incelendi. Hücre canlılığı inkübasyonun 24. ve 48. saatlerinde ölçüldü ve apiksaban en yüksek dilüsyonda toksik etki gösterdi. Diğer dilüsyonlar kontrol grubu ile benzer bulundu. Bu sonuçlar, apiksabanın yüksek dilüsyonda kanser hücrelerinin proliferasyonunu azaltabileceğini göstermektedir.
\end{abstract}

\section{Anahtar Kelimeler}

Apiksaban, yeni nesil oral antikoagulan, venöz tromboembolizm, sitotoksisite, HeLa hücreleri.

Article History: Received: Apr 10, 2018; Revised: May 18, 2018; Accepted: Jul 6, 2018; Available Online: Oct 4, 2018.

DOI: 10.15671/HJBC.2018.247

Correspondence to: E. Kubat, Hacettepe University, Faculty of Science, Department of Biology, Ankara, Turkey. 


\section{INTRODUCTION}

Trof hromboembolic diseases are the leading causes of death in developed countries. Oral anticoagulants are widely used for prevention of cardiac and venous thromboembolism (VTE). During the past six decades, vitamin $\mathrm{K}$ antagonists, such as warfarin, have been extensively used for anticoagulant therapy [1]. However, novel agents have recently been developed, as the use of vitamin $\mathrm{K}$ antagonists is limited due to the food interactions and need for monitoring. New oral anticoagulants (NOACs) are mainly activated factor Xa (FXa) or thrombin [1]. Apixaban is a highly selective and well-tolerated oral factor Xa inhibitor [2]. It has predictable pharmacokinetic properties and fixed-dose regimen. Apixaban has been widely used worldwide after the approval of the United States Food and Drug Administration (FDA) and by the European Medicine Agency (EMA) [1].

Thromboembolic disorder is a serious risk factor in cancer patients [3]. Acute VTE is the second leading cause of death after the malignancy itself. Recurrent VTE and bleeding complications are high risk factors in anticoagulant treatment for acute VTE in cancer patients $[4,5]$. Therefore, developing new modalities is highly important, and NOACs have the potential to be alternative options for these patients [4]. In addition to their benefits to prevent $\mathrm{VTE}$, anticoagulant drugs may have an inhibitory effect on tumor development and progression [6]. Recently, a FVIla inhibitor has been found to be an inducer of apoptosis in tumor cells through activating caspase cascade [7]. However, there is only a few data suggesting that anticoagulant drugs may have an inhibitory effect on cancer cells.

Cervical cancer is one of the primary causes of cancer-related deaths and new cases have been increasing every year all over the world [8]. Cervical adenocarcinoma (ADC) has an increasing prevalence unlike squamous cell-carcinoma (SCC) [9]. Cervical adenocarcinoma comprises nearly 20 to $25 \%$ of the all cervical malignancy in developed countries [10]. Three types of ADC occur in the cervix. Mucinous adenocarcinoma is the most common type of ADC in the cervix. Endometrial $A D C$ is a type that develops in the lining of the uterus. Clear-cell ADC may occur in daughters of women who used diethylstilbestrol during pregnancy [9]. HeLa cells are a line of human cells derived from cervical cancer [11]. These cells were isolated from a woman named Henrietta Lacks from her cervical tumor in 1951, which is currently known as the HeLa cells [12]. The HeLa cell line is an endocervical adenocarcinoma cells [13]. This cell line was the first cell line to survive outside the human body and grow. They have shown high durability and versatility and have been used for applications such as drug discovery, virus studies, and cancer researches [11]. In the present study, we aimed to investigate cytotoxic activity of apixaban on the HeLa cell lines derived from human cervical cancer.

\section{MATERIALS and METHODS}

\section{Cell Culture and Treatment of Test Material}

The HeLa cells were placed in 96-well culture plates (Greiner Bio-One, Germany) at an initial density of 30.000 cells $/ \mathrm{mL}$ in six replicates and incubated in the Dulbecco's Modified Eagle's Medium (DMEM)/Ham's F12 (Biowest Inc., Nuaillé, France) supplemented with $10 \%$ fetal bovine serum (FBS) (Biowest Inc., Nuaillé, France) in a humidified atmosphere of $95 \%$ air and $5 \% \mathrm{CO}_{2}$ for 12 hours at $37^{\circ} \mathrm{C}$. Following incubation, the cells were treated with five dilutions of the test material [Eliquis (apixaban, $5 \mathrm{mg})^{\mathrm{TM}}$ ]. Test material was prepared in (DMEM)/Ham's F12 supplemented with $1 \%$ dimethyl sulfoxide (DMSO) (Sigma Chemical Co., St. Louis, MO), which is a safe organic solvent to prepare solutions used in cell culture tests. Stock solution was prepared as $0.30 \mathrm{~g} / 20 \mathrm{~mL}$ for the initial dose, according to the molecular weight of the agent (apixaban: $459.506 \mathrm{~g} / \mathrm{moL}$ ). Stock solution was kept at room temperature for 24 hours and, then, filtered using $0.8 \mu \mathrm{m}$ and $0.2 \mu \mathrm{m}$ filters before use. Five dilutions of test material were prepared in (DMEM)/Ham's F12 medium containing 10\% FBS by serial dilution [Dilution I (stock solution): $30 \mu \mathrm{M}$; Dilution II: $15 \mu \mathrm{M}$; Dilution III: $7.5 \mu \mathrm{M}$; Dilution IV: $3.75 \mu \mathrm{M}$; Dilution V: 1.875 $\mu \mathrm{M}]$.

\section{Cell Morphology}

Morphological changes of the cells were examined under an inverting microscope (IX70 Olympus, Japan). All groups within test series were compared with the control group separately for each evaluation period. 


\section{Cell Viability}

The cell viability was determined by MTT assay. The viability of HeLa cells was examined at 24 and 48 post-incubation hours. At each evaluation period, the culture medium was removed, and $100 \mu \mathrm{L}$ DMEM/F12-without FBS containing 12.5 $\mu \mathrm{L}$ MTT were added into each well. Culture plates were covered with aluminum foil and cells were, then, incubated in the dark for four hours. At the end of the incubation period, MTT solution was removed from the wells and $100 \mu \mathrm{L}$ isopropyl alcohol was added. The absorbance at $560 \mathrm{~nm}$ was measured using an ultraviolet (UV)-visible spectrophotometer (EZ Read 400 Microplate Reader, Biochrom).

\section{Statistical Analysis}

Statistical analysis was performed using the SPSS version 23.0 software (IBM Corp., Armonk NY, USA). Descriptive statistics were expressed in mean values \pm standard deviation (SD). The Kolmogorov-Smirnov test was used for the normality test. The analysis of variance (ANOVA) was used to compare the means of more than two groups. A post-hoc test (Tukey test or Tamhane's test) was used to examine significant differences between the groups. A $p$ value less than 0.05 was considered statistically significant.

\section{RESULTS and DISCUSSION Cell Morphology}

At 24-hour incubation, the cells exposed to dilution I of apixaban showed a significant difference, compared to normal fibroblastic morphology. The cells displayed degeneration as nuclear condensation and rounded cell morphology. Cells in dilutions II, III, IV, and V demonstrated a similar fibroblastic morphology with the control cells (Figure 1a-f).

At 48 hours, the cells did not show significant morphological changes, compared to the cells at 24 hours in all dilutions of the test material.

\section{Cell Viability}

The viability of HeLa cells was examined for the test material in different dilutions and compared with the control group at 24 and 48 hours

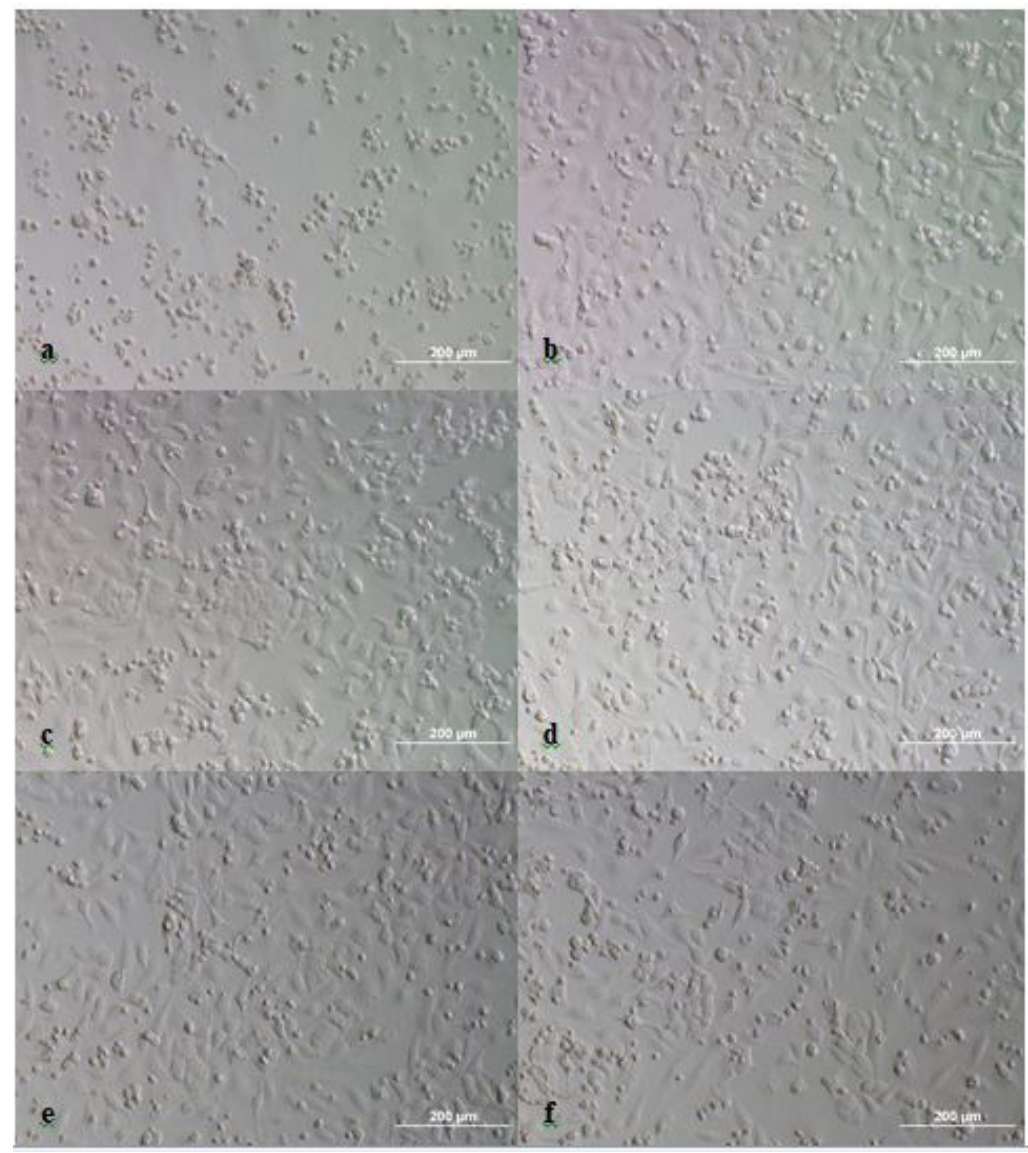

Figure 1. Morphological appearance of HeLa cells exposed to apixaban at 24 hours of incubation. Dilution I (a); Dilution II (b); Dilution III (c); Dilution IV (d); Dilution V (e); Control (f) (10x). 
after incubation (Figure 2). Apixaban showed a cytotoxic effect in the highest dilution (Dilution I).

In other dilutions cell viability is similar with control group except for dilution 4. It can be said that initial density of cells in this dilution is higher than in the other dilutions.

The Tukey test or Tamhane's test was performed to show the difference between the dilutions and control group (Table 1). These result indicated that apixaban might reduce proliferation of cancer cells in high dilutions.

The ANOVA was performed to evaluate significant differences among all dilutions at 24 and 48 hours and $p$ value was obtained. The results showed that cell viability was statistically significant in all dilutions between 24 and 48 hours, except for Dilution I (Table 2). This result indicated that Dilution I had a cytotoxic activity both at 24 and 48 hours of incubation.

Apixaban [1-(4-methoxyphenyl)-7-oxo-6-[4(2-oxopiperidin-1-yl) phenyl]-4,5,6,7-tetrahydro$1 \mathrm{H}$-pyrazolo[3,4-c]pyridine-3-carboxamide $\mathrm{C}_{25} \mathrm{H}_{25} \mathrm{~N}_{5} \mathrm{O}_{4}$ ] is a direct oral $\mathrm{FXa}$ inhibitor which has rapid absorption and 12-hourhalf -life [14]. It has good bioavailability, low clearance, and a small volume of distribution and it shows low drug-drug interactions. Apixaban is highly selective for the prevention and treatment of thromboembolic diseases [15]. As thrombin plays a key role in the generation of an occlusive thrombus, inhibition of thrombin activity becomes a major target in the developing of novel antithrombotic agents. The direct $F X a$ inhibitors, such as apixaban, inhibit thrombin production by blocking the $\mathrm{FXa}$ in the blood coagulation cascade. Apixaban is a highly potent, reversible, and active-site inhibitor of human $\mathrm{FXa}$, with a $\mathrm{Ki}$ of $0.08 \mathrm{nM}$ at $25^{\circ} \mathrm{C}$ and $0.25 \mathrm{nM}$ at $37^{\circ} \mathrm{C}$ in the $\mathrm{FXa}$ tripeptide substrate assay [16]. Analysis of enzyme kinetics shows that apixaban act as a competitive inhibitor of FXa binding its active site. The reversibility of FXa inhibition is demonstrated by the recovery of FXa activity at $37^{\circ} \mathrm{C}$. Apixaban has over 30.000fold higher selectivity for FXa, compared to other human coagulation proteases and related enzymes [17].

Apixaban is a pyrazole-based drug and it has been reported that the pyrazoles show anticancer activity by inhibiting topoisomerase lla [18]. Deoxyribonucleic acid (DNA) topoisomerase has been recognized as an important target in anticancer drug discovery [19]. Topoisomerases (I and II) are essential nuclear enzymes that
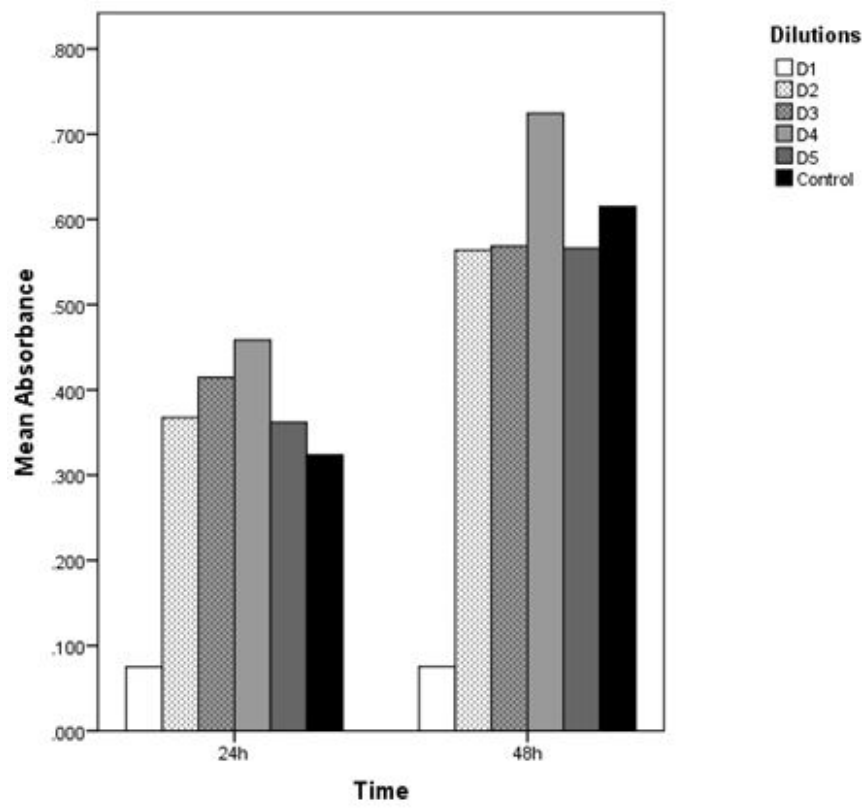

Figure 2. Comparison of cell viability at 24 and 48 hours in different dilutions. 
Table 1. Cell viability of the test material at 24 and 48 hours in each dilution compared to control group.

\begin{tabular}{|c|c|c|c|c|}
\hline Time & Dilutions & Mean Absorbance & Standard deviation & $\mathrm{p}$ \\
\hline \multirow{6}{*}{$24 \mathrm{~h}$} & D1 & 0.075 & 0.0007 & $<0.001^{*}$ \\
\hline & D2 & 0.367 & 0.054 & 0.692 \\
\hline & D3 & 0.415 & 0.047 & 0.050 \\
\hline & D4 & 0.458 & 0.061 & $0.001^{*}$ \\
\hline & D5 & 0.362 & 0.054 & 0.793 \\
\hline & Control & 0.324 & 0.066 & - \\
\hline \multirow{6}{*}{$48 \mathrm{~h}$} & D1 & 0.075 & 0.009 & $<0.001^{*}$ \\
\hline & D2 & 0.564 & 0.087 & 0.996 \\
\hline & D3 & 0.569 & 0.105 & 1.000 \\
\hline & D4 & 0.725 & 0.119 & 0.764 \\
\hline & D5 & 0.566 & 0.123 & 1.000 \\
\hline & Control & 0.615 & 0.076 & - \\
\hline
\end{tabular}

$p$ values compared to control group

Table 2. Comparison of cell viability of test material at 24 and 48 hours for each dilution.

\begin{tabular}{lcccc}
\hline Dilutions & Time & Mean Absorbance & Standard deviation & $p$ \\
\hline D1 & 24 & 0.075 & 0.007 & $0.916>0.05$ \\
& 48 & 0.075 & 0.009 & $0.001<0.05^{*}$ \\
\hline D2 & 24 & 0.367 & 0.054 & $0.008<0.05^{*}$ \\
\hline D3 & 48 & 0.564 & 0.087 & 0.047 \\
\hline \multirow{2}{*}{ D4 } & 24 & 0.415 & 0.105 & $0.002<0.05^{*}$ \\
\hline \multirow{2}{*}{ D5 } & 48 & 0.569 & 0.061 & $0.004<0.05^{*}$ \\
\hline \multirow{2}{*}{ Control } & 24 & 0.458 & 0.119 & 0.054 \\
\hline
\end{tabular}

maintain the topological changes of DNA and play key role in transcription, replication, and chromosome segregation [20]. Anticancer drugs are designed as topoisomerase I and II inhibitors [19]. These drugs are classified into two groups: topoisomerase II poisons and topoisomerase II catalytic inhibitors. Topoisomerase II poisons stabilize the cleavable complex of topoisomerase II with DNA by constituting the covalent ternary complex of drug/agent-cleaved $G$ segment, and enzyme release and stimulate apoptosis.
Topoisomerase catalytic inhibitors play role in any of the other step of catalytic cycle. Recently, pyrazole-based new agents designed, synthesized and the cytotoxic effects on different cancer cell lines have been studied [21].

The possibility of VTE being seen is very high in cancer patients and metastasis also increases VTE risk [3]. The increase of VTE risk is even higher in metastasis of aggressive types of cancers. Besides VTE, patients with cancer have several 
bleeding risk factors (i.e., chemotherapy-induced thrombocytopenia, disseminated intravascular coagulation and renal or liver impairment). Cervical cancer is one of the most common malignant tumors affecting women [22]. Venous thromboembolism is also a life-threatening condition which occurs as a complication of cervical cancer [23]. Therefore, effective and safe anticoagulant therapy is of utmost importance in cancer patients and NOACs may be an option for these patients.

Apixaban has been recommended as an alternative to low-molecular-weight heparin for cancer patients with VTE [24]. In an animal model, it was shown that the seeding of tumor metastases was a coagulation-dependent process [25]. In addition, an animal experimental study showed that tissue factor pathway inhibitor, a physiological FXa inhibitor, and the nematode anticoagulant protein rNAPc2 inhibited primary and metastatic tumor growth in mice [26]. Amblyomin-X, a Kunitz type FXa inhibitor, showed cytotoxic effects in cancer cells through inducing apoptosis and promoting cell cycle arrest [27]. In addition, secreting procoagulant and antifibrinolytic factors from cancer cells were shown to cause endothelial damage by inflammatory process [28]. The molecular mechanism underlying the link between anticoagulant drugs and tumor biology are not known exactly [29]. Therefore, more definitive and comprehensively experimental studies are needed to investigate this correlation.

As apixaban has a lower bleeding profile different from the other NOACs and it has a possible inhibitor effect on cancer cells [30], it can be a good choice for cancer patients. In a study, cytotoxic effects of synthesized lactam derivatives and rivaroxaban were investigated on HCT-116, HeLa, and HEK-293 cells lines [31]. In another study, in vitro effects of apixaban on five different cancer cell lines were investigated [6]. In this study, cell proliferation and mortality were investigated on OVCAR3 (ovarian cancer), MDA MB 231 (breast cancer), CaCO-2 (colon cancer), LNCaP (prostate cancer), and U937 (histiocytic Iymphoma) in apixaban-treated cultures. Reduced proliferation was seen in three cancer cell lines
(OVCAR3, CaCO-2 and LNCaP) and increased cell mortality was seen in four cancer cell lines (OVCAR3, MDA MB 231, CaCO-2, and U937). Similar to our study, the increased cancer cell mortality was found during high-dose apixaban incubation[6]. In our study, direct cytotoxic effect of apixaban on cervical cancer cell line was shown only high-dose exposure of apixaban.

Nonetheless, our study has some limitations. First, the experiments were performed in a cell culture milieu which contained $10 \%$ fetal bovine serum which induces proliferation of cell, and this may be explained increased cell number at 48 hours of incubation period. The other one, cell migration, gene expression and matrix metalloproteinase in cancer cell lines was not investigated in our study, only cytotoxic data was available.

In conclusion, cytotoxic activity of apixaban on HeLa cells was investigated an in vitro cervical tumor model. Our results showed that apixaban may reduce proliferation of cancer cells in high dilutions at 24 and 48 hours. We believe that investigation of cytotoxic effects of this drug should be considered a preliminary study and more detailed studies are needed to explain the cytotoxic mechanism of the drug. To the best of our knowledge, this is the first study in the literature about apixaban cytotoxicity on HeLa cells. Experimental studies should be performed to reveal further data for effect mechanism of apixaban on HeLa cells.

\section{References}

1. A. Di Minno, B Frigerio, G. Spadarella, A. Ravani, D. Sansaro, M. Amato, J.P. Kitzmiller, M. Pepi, E. Tremoli, D. Baldassarre, Old and new oral anticoagulants: Food, herbal medicines and drug interactions. Blood. Rev., 31 (2015) 193-203.

2. C. Frost, J. Wang, S.Nepal, A. Schuster, Y.C. Barrett, R. Mosqueda-Garcia, R.A. Reeves, F. LaCreta, Apixaban, an oral, direct factor Xa inhibitor: single dose safety, pharmacokinetics, pharmacodynamics and food effect in healthy subjects. BJCP. 75 (2012) 476-487.

3. G.T. Gerotziafas, I. Mahé, I. Elalamy, New orally active anticoagulant agents for the prevention and treatment of venous thromboembolism in cancer patients. Ther. Clin. Risk. Manag., 10 (2014) 423-426. 
4. T.V. Der Hulle, P.L. Den Exter, J. Kooiman, J.J.M. Van der Hoeven, M.V. Heismen, F.A. Klok, Meta-analysis of the efficacy and safety of new oral anticoagulants in patients with cancer-associated acute venous thromboembolism. J. Thromb. Haemost., 12 (2014) 1116-1120.

5. M.N. Levine, C. Gu, H.A. Liebman, C.P. Escalante, S. Solymass, D. Deitchman, L. Ramirez, J. Julian, A randomized phase II trial of apixaban for the prevention of thromboembolism in patients with metastatic cancer. J. Thromb. Haemost., 10 (2012) 807-814.

6. L. Guasti, A. Sqizzato, P. Moretto, D., Vigetti, W. Agero, F. Dentali, A.M. Moresca, L. Campiotti, A.M. Grandi, A. Passi, In vitro effects of Apixaban on 5 different cancer cell lines. PlosOne, 12 (2017) 1-19.

7. T.A. Hambrough, G.M. Swartz, A. Papathanassiu, G.P. Vlasuk, W.E. Rote, S.J. Green, V.S. Pribluda, Tissue Factor/Factor VIla Inhibitors Block Angiogenesis and Tumor Growth Through a Nonhemostatic Mechanism. Cancer Res., 63 (2003) 2997-3000.

8. J. Ferlay, I. Soerjomataram, R. Dikshit, S. Eser, C. Mathers, M. Rebelo, D. M. Parkin, D. Forman, F. Bray, Cancer incidence and mortality worldwide: Sources, methods and major patterns in GLOBOCAN 2012. IJC, 136 (2015) 359-386.

9. S. Takeuchi, Biology and treatment of cervical adenocarcinoma. Chin. J. Cancer Res., 28 (2016) 254 262.

10. E.C. Pirog, Cervical Adenocarcinoma: Diagnosis of Human Papillomavirus-Positive and Human Papillomavirus-Negative Tumors. Arch. Pathol. Lab. Med. 241 (2017) 1653-1667.

11. J.J. M. Landro, P.T. Pyl, T. Rausch,T. Zichner, M.M. Tekkedil, A.M. Stütz, A. Jauch, R.S. Aiyar, G. Pau, N. Delhomme, J. Gagneur, J.O. Korbel, W. Huber, L.M. Steinmetz, The Genomic and Transcriptomic Landscape of a HeLa Cell Line. Genes Genoms Genetics. 3 (2013) 1213-1224.

12. B.P. Lucey, W.A. Nelson-Rees, G.M. Hutchins, Henrietta Lacks, HeLa Cells, and Cell Culture Contamination. Arch. Pathol. Lab. Med. 133 (2009) 1463-1467.

13. J.M.E. Contreras-Ortiz, J.C. Vázquez-Chagoyán, J.S. Martínez-Castañeda, J.G. Estrada-Franco, J.E. Aparicio-Burgos, J. Acosta-Dibarrat, A. BarbabosaPliego, Resistance of cervical adenocarcinoma cells (HeLa) to venom from the scorpion Centruroides limpidus limpidus. JVATITD. 19 (2013) 1-7.

14. P.C. Wong, D.J.P. Pinto, D. Zhang, Preclinical discovery of apixaban, a direct and orally bioavailable factor Xa inhibitor. J. Thromb. Thrombolysis. 31 (2011) 478-492.

15. P.C. Wong, E.J. Crain, B. Xin, R.R. Wexler, P.Y.S. Lam, D.J. Pinto, J.M. Luettgen, R.M. Knabb, Apixaban, an oral, direct and highly selective factor $\mathrm{Xa}$ inhibitor: in vitro, antithrombotic and antihemostatic studies. J. Thromb. Haemost. 6 (2007) 820-829.

16. J.M. Luettegen, R.M. Knabb, K. He, D.J.P. Pinto, A.R. Rendia, Apixaban inhibition of factor Xa: Microscopic rate constants and inhibition mechanism in purified protein systems and in human plasma. J. Enzym. Inhib. Med. Ch. 26 (2011) 514-526.
17. D.J. Pinto, M.J. Orwatt, S. Koch, K.A. Rossi, R.S. Alexander, A. Smallwood, P.C. Wong, A.R. Rendina, J.M. Luettegen, R.M. Knabb, K. He, B. Xin, R.R. Wexler, P.Y. Lam, Discovery of 1-(4-methoxyphenyl)-7-oxo6-(4-(2-oxopiperidin-1-yl)phenyl)-4,5,6,7-tetrahydro$1 \mathrm{H}$-pyrazolo[3,4-c]pyridine-3-carboxamide (apixaban, BMS-562247), a highly potent, selective, efficacious, and orally bioavailable inhibitor of blood coagulation factor Xa. J. Med. Chem. 50 (2007) 5339-5356.

18. R. Alam, D. Wahi, R. Singh, D. Sinha, V. Tandan, A. Graver, Rahisuddin, Design, synthesis, cytotoxicity, HuTopolla inhibitory activity and molecular docking studies of pyrazole derivatives as potential anticancer agents. Bioorg. Chem. 69 (2016) 77-90.

19. A.T. Baviskar, C. Madaan, P. Mohaptra, V. Jain, A. Agrawal, S.K. Guchhait, C.N. Kundu, U.C. Banerjee, $\mathrm{N}$-Fused Imidazoles As Novel Anticancer Agents That Inhibit Catalytic Activity of Topoisomerase IIr and Induce Apoptosis in G1/S Phase. J. Med. Chem. 54 (2011) 5013-5030.

20. J.J. Champoux, DNA Topoisomerases: Structure, Function, and Mechanism. Annu. Rev. Biochem. 70 (2001) 369-413.

21. R. Alam, A. Alam, A.K. Panda, Rahisuddin, Design, synthesis and cytotoxicity evaluation of pyrazolyl pyrazoline and pyrazolyl aminopyrimidine derivatives as potential anticancer agents. Med. Chem. Res.27 (2018) 560-570.

22. H. Li, X. Wu, X. Cheng, Advances in diagnosis and treatment of metastatic cervical cancer. J. Gynecol. Oncol. 27 (2016) 1-20.

23. S.J. Tsai, Y.X. Ruan, C.C. Lee, M.S. Lee, W.Y. Chiou, H.Y. Lin, F.C. Hsu, Y.C. Su, S.K. Hung, The incidence of venous thromboembolism in cervical cancer: a nationwide population-based study. BMC Research Notes. 5 (2012) 316-321.

24. G. Agnelli, H.R. Buller, A. Cohen, A.S. Gallus, T.C. Lee, R. Pak, G.E. Raskob, J.I. Weitz, T. Yamabe Oral apixaban for the treatment of venous thromboembolism in cancer patients: results from the AMPLIFY trial. J. Thromb. Haemost. 13 (2015) 2187-2191.

25. J.S. Palumbo, K.W. Kombrinck, A.F. Drew, T.S. Grimes, J.H. Kiser, J.L. Degen, T.H. Bugge, Fibrinogen is an important determinant of the metastatic potential of circulating tumor cells. Blood. 96 (2000) 3302-3309.

26. T.A. Hembrough, G.M. Swartz, A. Papathanassiu, G.P. Vlasuk, W.E. Rote, S.J. Green, V.S. Pribluda, Tissue factor/factor VIla inhibitors block angiogenesis and tumor growth through a nonhemostatic mechanism. Cancer. Res. 63 (2003) 2997-3000.

27. J.S. Ventura, F. Faria, I.F.C. Batista, S.M. Simons, D.G.L. Oliveira, K.L.P. Morais, A.M. Chudzinski-Tavassi, A Kunitz-type FXa inhibitor affects tumor progression, hypercoagulable state and triggers apoptosis. Biomed Pharmacother. 67 (2013) 192-196.

28. A.C. Matzdorff, D. Green, Coagulation in Cancer, Springer Science Business Media, 2009.

29. N. Zhang, W. Lou, F. Ji1, L. Qiu, B.K. Tsang, W. Di, Low molecular weight heparin and cancer survival: clinical trials and experimental mechanisms. J. Cancer Res. Clin. Oncol. 142 (2016) 1806-1816. 
30. E.L. Hellenbart, K.D. Faulkenberg, S.W. Finks, Evaluation of bleeding in patients receiving direct oral anticoagulants. Vasc. Health Risk. Manag. 13 (2017) 325-342.
31. N.E. Núñez-Navarro, G.F. S. Renato A. Burgos, C.F. Lagos, N. Fuentes-lbacache, M.A. Faúndezb, F.C. Zacconi, Microwave Assisted Synthesis of Novel SixMembered 4-C, 4-O and 4-S Lactams Derivatives: Characterization and in vitro Biological Evaluation of Cytotoxicity and Anticoagulant Activity. J. Braz. Chem. Soc., 28 (2017) 203-207. 